Journal of Muslim Minority Affairs

\title{
Islamic Finance for Consumers in Ireland: A Comparative Study of the Position of Retail-level Islamic Finance in Ireland
}

\section{Edana Richardson}

To cite this article: Edana Richardson (2011) Islamic Finance for Consumers in Ireland: A Comparative Study of the Position of Retail-level Islamic Finance in Ireland, Journal of Muslim Minority Affairs, 31:4, 534-553, DOI: 10.1080/13602004.2011.630861

To link to this article: https://doi.org/10.1080/13602004.2011.630861

Published online: 15 Dec 2011.

Submit your article to this journal ऍ

Џلll Article views: 303

4 Citing articles: 3 View citing articles ๘ 


\title{
Islamic Finance for Consumers in Ireland: A Comparative Study of the Position of Retail-level Islamic Finance in Ireland
}

\section{EDANA RICHARDSON}

\begin{abstract}
The Irish Government's public interest in Islamic finance has occurred only recently, with the publication of the Tax Briefing 2009 and the modifications to the Taxes Consolidation Act 1997, introduced by the Finance Act 2010. Echoing developments in other non-Islamic countries, these instruments attempt to facilitate the development of Islamic finance in Ireland by removing legislative obstacles faced by Islamic financial products, and by clarifying the tax position of these transactions. However, notwithstanding publicity suggesting that the Irish economy is now open to Islamic financial activity, this accommodation has not extended, in practice, beyond the wholesale Islamic finance market. Retail-level Islamic finance in Ireland therefore remains undeveloped and stymied by regulatory and taxation burdens. Focusing on domestic Islamic finance activity, this article will consider the current legal position of Islamic finance in Ireland. Using Islamic mortgage-alternatives as an example, it will discuss the continuing difficulties faced by those who wish to participate in Islamic retail finance. It will also present recommendations on how this sector could be more successfully integrated into the Irish legal framework.
\end{abstract}

\section{Introduction}

Islamic finance, ${ }^{1}$ or financial activity which is structured so as to align with the teachings of Islamic law ( $\left.\operatorname{shari}^{-} a h\right)$, represents a latter-day manifestation of religious adherence which has garnered broad, and growing, recognition across the world. ${ }^{2}$ Even in jurisdictions where religion has been largely removed from the public sphere and has taken on a private, voluntary role in the lives of citizens, Islamic finance has at times been openly facilitated and publicly promoted by government authorities. ${ }^{3}$ It could, somewhat flippantly, be said that Islamic finance is one of the success stories of Islam in the West.

Driven by a resurgence of Islamic revivalist views, ${ }^{4}$ disenchantment with some conventional financial products, ${ }^{5}$ and growing wealth in numerous Muslim states, ${ }^{6}$ the Islamic finance industry has developed rapidly over the last 40 years, particularly in the last decade. With global assets now worth over $\$ 1$ trillion, ${ }^{7}$ Islamic finance has assumed more mainstream relevance with shari'ah-compliant financial products available for both wholesale, sophisticated financial activity and retail-level transactions. In Ireland, official consideration of Islamic finance has only occurred recently with the publication of the Revenue Commissioners' Tax Briefing in October $2009^{8}$ and the passing of the Finance Act in February 2010. ${ }^{9}$ Both of these instruments contain provisions which address the position of Islamic finance in Ireland's taxation regime. In doing so, the Briefing and relevant sections of the Act seek to clarify the tax treatment of a broad range of Islamic finance products, many of which had previously received no specific consideration 
by Irish authorities. Ireland's initial steps to facilitate Islamic finance activity are not, however, entirely innovative and instead follow other countries, both Muslim and nonMuslim, which have sought to regulate and harmonize Islamic financial products within their economies. ${ }^{10}$ Unlike commentary in countries such as the UK and USA however, ${ }^{11}$ discussion of the benefits and implications of an Islamic finance sector within Ireland's economy has almost exclusively focused on the wholesale sector and the potential for the International Financial Services Centre (IFSC) in Dublin to attract sharī $a h$-compliant investment from abroad. As a result, very little consideration has been given to the current position of Muslims in Ireland who would consider participating in financial activity which is consistent with their religious beliefs. ${ }^{12}$

This article will consider what, if any, impact recent attempts by the Irish Government to accommodate certain Islamic financial structures will have on consumers who wish to use Islamic retail products. It will first attempt to contextualize the contemporary Islamic finance industry and will discuss the core prohibitions which underpin sharl' $a h$-compliant financial activity. It will outline the Government's motivations for this accommodation and consider whether the development of consumer banking services, which adhere to Islamic financial principles, can be justified. Focusing on Islamic mortgage-alternatives, it will conclude by outlining the continuing difficulties faced by those in Ireland who attempt to conduct their financial affairs in a sharī'ah-compliant manner.

\section{Islamic Banking and Finance}

Though references to economic principles in the Qur'ān and Sunnah are often obscure and dispersed, the Qur'ân contains explicit approval of the interrelationship between economics and religion when it notes that "Allah has permitted trading", ${ }^{13}$ and when it calls on Muslims to "spend their wealth (in Allah's Cause)". ${ }^{14}$ Broad endorsement is not, however, the limit of shari' $a$ 's intervention in financial activity. Indeed, the roots of Islamic law have been interpreted by classical scholars as establishing basic precepts to which Islamic finance services and products should adhere: the prohibition of interest $(r i b \bar{a})$, the avoidance of gambling and speculation (maysir), the need to limit uncertainty in a contract (gharar), and finally, the unlawfulness of certain forbidden (harām) activities. These principles represent the theological norms upon which the Islamic finance industry rests and the structural parameters of $\operatorname{shari}^{-} a h$-compliant financial activity. As a condition precedent to religious conformity therefore, deliberate avoidance of rib $\bar{a}$, maysir, gharar, and harām activities distinguishes Islamic financial activity from conventional, secular alternatives and is the basic reason why a discrete Islamic finance industry exists. $^{15}$

\section{$R i b \bar{a}$}

The two divine roots of Islamic law reject ribā with verse 2:275 of the Qur'ān noting that "[t]hose who took riba shall be raised like those who have been driven to madness by the touch of the Devil". ${ }^{16}$ Though the term is not explained in the Qur'ān or Sunnah, ribā means increase and in an Islamic context, has been interpreted by many classical scholars as unjustified gain resulting from an unfair exchange of counter-values between contractual parties. ${ }^{17}$ The scope of this prohibition has been subject to scholarly debate, however, when applied to contemporary financial activity, Islamic law's rejection of riba has been used as the immutable basis for declaring that all interest-bearing financial transactions are contrary to Islam and void. ${ }^{18}$ As a result neither Muslims, nor financial institutions 
which purport to act in accordance with the principles of contemporary Islamic finance, should charge or receive interest.

Numerous Islamic scholars have justified the prohibition on the basis that in Islam, money itself in not considered to have any intrinsic value. Currency should only have value as a medium of exchange rather than as a commodity for exchange. ${ }^{19}$ Charging interest on money borrowed is therefore regarded as sterile, as the wealth made by the lender is not in any way the product of that lender's work. ${ }^{20}$ Instead, participants in financial activity are encouraged to earn legitimate profit through risk sharing and effective involvement in economically beneficial activity. Such profits are valid because they are not the product of idle gain but arise, rather, through calculated entrepreneurial risk and active participation in a transaction. ${ }^{21}$

\section{Maysir and Gharar}

Like the prohibition of ribāa, the proscriptions of gambling (maysir) and uncertainty (gharar) find support in the roots of Islamic law. ${ }^{22}$ Preventing speculation, exploitation and unfair gain, these roots have been interpreted as forbidding games of chance and all kinds of gambling which allow someone to get something too easily. ${ }^{23}$ With maysir explicitly classified by the Qur'an $n$ as the "work of the devil", ${ }^{24}$ its prohibition has been relied on by Islamic scholars to prevent not simply explicit forms of gambling but also business activities which contain guesswork and conjecture; transactions which are based on pure speculation are therefore forbidden. ${ }^{25}$

Linked to the notion of speculation as illegitimate in Islamic finance, the prohibition of gharar acts to prevent activity in which there is an excessive level of uncertainty, ignorance or confusion. Though legitimate business risk is permitted and indeed encouraged in Islam, ${ }^{26}$ this third prohibition renders illegitimate, financial activity in which there is transactional unfairness to one or both of the parties. ${ }^{27}$ Building upon this, no commercial venture is to be entered into blindly ${ }^{28}$ and contracts are only valid if they are devoid of insecurity. ${ }^{29}$ In conventional, commercial transactions therefore, the prohibition of gharar manifests itself in an understanding that "there should not be uncertainty, ambiguity or deception ... [a] financial contract should not lack specificity in its terms". ${ }^{30}$

\section{Harām Investments and the Promotion of Ethics}

Finally, in addition to fetters on how commercial transactions should be structured, Islamic economic principles also place strict limits on the type of activity, transaction, or company that can be invested in. Essentially, a sectoral screening is established which prohibits association with industries considered to promote vice. ${ }^{31}$ Key among these are matters explicitly prohibited by the Qur'ān or the Sunnah including the making or selling of alcohol, pornography, and pork products. ${ }^{32}$ Earning money through involvement in prohibited industries is forbidden (harām) and Muslims must refrain from any connection with such activities, whether directly or indirectly through investment in related businesses. ${ }^{33}$

Islamic financial activity, unlike the conventional finance industry, is thus constrained by supra-social, non-temporal principles to which it must conform. The prohibitions of ribā, maysir, gharar, and harām activity, which are frequently depicted as facilitating the realization of shari' $a h$ 's broader goals, require Islamic market participants to consider issues other than maximum economic success when developing and using financial instruments. In theory, financial activity which is underpinned and guided by moral 
goals is an attractive proposition. In practice however, compliance with the dictates of Islamic law has not been a straightforward exercise for market participants, particularly in non-Muslim countries.

\section{Islamic Finance and Ireland}

\section{Islamic Finance and Capitalism}

In Ireland, as with other Western states, religion and economics remain distinct disciplines which are rarely, if ever, explicitly intermingled. For some commentators, the unique calibration of Islamic finance, which attempts to fulfill religious precepts and to uphold the ethical principles of Islamic law, stands in contrast to the basic philosophy of nonIslamic economies. The separation of ethics and economics is blamed for the "unhindered pursuit of self-interest by individuals... [and] other insoluble social evils" ${ }^{34}$ resulting from capitalism as well as the "dialectics, indiscriminate liquidation and expropriation" 35 of socialism. By way of contrast, Islamic economics is venerated as promoting equity, communal justice, the prevention of exploitation, the protection of private property and the elimination of greed. ${ }^{36}$ Such criticisms of other economic systems and suggestions that Islamic finance can only really be successful when part of a full-scale Islamization of society, ${ }^{37}$ raises the question of whether Islamic finance could ever form part of the Irish economic framework since it could be assumed that Islamic financial principles are irreconcilable with the very essence of Ireland's capitalist system.

In reality, a successful, fully Islamic economy has yet to be achieved anywhere ${ }^{38}$ and as indicated by the growth of Islamic finance in Europe, the USA, and Australia, the Islamic finance industry can and does operate in economies founded on non-Islamic ideals. ${ }^{39}$ Financial activity in capitalist economies, particularly at retail level, is not entirely unchecked nor devoid of principles; many of the secular laws enacted today relating to consumer protections, director's fiduciary duties, the prevention of unfair dealing and fraud seek to rein in the unbridled individual freedom apparently conferred by capitalism. Similarly, the presence of ethical investment funds in Ireland's financial market indicates that the conflation of moral responsibility and economics found in Islamic finance is not a novel concept in the Irish economy. While profit and economic success are aims of Ireland's economic participants therefore, social issues and the wider implications of economic activity also form part of the capitalist process.

The world's Muslim population is not a self contained coterie located in a single area but is, rather, dispersed across multiple jurisdictions, both Muslim and non-Muslim. In Ireland alone for example, there were 32,539 Muslims living in the Republic according to the 2006 Census, an increase of almost 70 per cent since $2002 .{ }^{40}$ While Islamic finance conducted in Ireland will not therefore form part of a movement towards greater Islamization of Irish society, it could provide a discrete social minority with an ethically guided mechanism through which they can participate in the financial sector. As simply an alternative form of financial activity, there is no ideological reason why Islamic finance could not function within Ireland's economy. As a result, the overt ethical overtones of Islamic finance should not be used by Irish authorities to justify inaction in relation to its integration.

\section{Tax Briefing and Finance Act}

The fact that Islamic finance can exist within an economy which is not underpinned by Islamic principles does not, however, mean that those religious principles have no impact 
on Islamic finance activity itself. As a result of the economic prohibitions found in the roots of Islamic law, Muslims cannot use many of the transactions and services offered by conventional financial institutions as these often involve payments of interest, speculation and interaction with non-shari ${ }^{-} a h$-compliant sectors. A range of Islamic finance products and services have therefore been engineered so that they are shari $\bar{r}^{-} a h$-compliant but also capable of functioning within contemporary financial markets. To ensure adherence to the principles of Islamic finance, these instruments are based on the "nominate contracts" which were established by classical Islamic scholars. ${ }^{41}$ These nominate contracts rely on profit and loss sharing, partnership, leasing and sale as mechanisms through which financial activity can be conducted without violating the prohibitions of ribā, maysir, and gharar. ${ }^{42}$ However, the Islamic finance transactions available to Muslims today are not limited to a set of simple contracts used in antiquity. ${ }^{43}$ To provide those using Islamic finance with the same financial choices and options as other market participants, contemporary Islamic products modify the manner in which the classical nominate contracts are used so as to replicate the economic outcome and impact of conventional products, ${ }^{44}$ albeit in a shari' $a h$-compliant manner. ${ }^{45}$ The substance of Islamic finance transactions is therefore similar to conventional products; the methodology and structure used to achieve this substance are, however, distinct. ${ }^{46}$

The bifurcated nature of contemporary Islamic finance has allowed those using Islamic financial products to comply with their religious beliefs while still ensuring that the products they use are comparable to the conventional structures they are substituting. It has, however, raised difficulties in terms of the treatment of such products within the context of an established legal system. As will be discussed in more detail below, in the context of sharī'ah-compliant mortgage-alternatives, the distinctive structure of Islamic finance products sits uneasily within tax, regulatory and other legislative provisions which were developed for interest-based financing. The structure of Islamic finance products may thus result in legal treatment of such products which is inconsistent with their substance and, by implication, with the treatment of economically comparable conventional structures. As a direct result of this potentially anomalous treatment of Islamic finance activity, several national regulatory and financial authorities have supported methods of integrating Islamic finance products which are tailored to accommodate the unique structural characteristics of these products. ${ }^{47}$ Amongst the most active of such authorities are those in the UK where Government policy has endeavored "to create the right conditions in the UK for Islamic finance to grow" 48 and ultimately to position the UK as a hub for Islamic finance. ${ }^{49}$ In relation to both regulation and taxation of Islamic finance, UK authorities have adopted an approach which seeks to encourage Islamic finance through the establishment of a level playing field between conventional and Islamic finance thus ensuring that "no obstacles, no special favours" are applied to "alternative [i.e. Islamic] finance arrangements". 50 The aim has therefore been to put Islamic finance on an equal footing with conventional structures so as to facilitate fair competition between financial products. ${ }^{51}$

In Ireland, the Revenue Commissioners' Tax Briefing in 2009 and the subsequent provisions of the Finance Act 2010 both addressed the taxation of several Islamic finance structures. The Briefing makes no legislative modifications but confirms that three Islamic products, takâful (Islamic insurance), ijärah (Islamic leasing), and Islamic funds, will be subject to the same tax regime as their non-Islamic counterparts. ${ }^{52}$ The Finance Act 2010 similarly deals with the tax treatment of three Islamic structures, "deposit transactions" (Islamic deposits), "credit transactions" (financing transactions), and "investment transactions" (sukük or Islamic bonds). ${ }^{53}$ However, unlike the Briefing, 
which simply confirms the application of Ireland's established tax law, the Finance Act amends a number of provisions of that tax law ${ }^{54}$ in order to accommodate a new category of structured product- "Specified Financial Transactions". ${ }^{55}$ In doing so, the Finance Act does not refer explicitly to Islamic finance or to shari $a h$ and instead uses shari $a h$ neutral language to describe the relevant financial structures. ${ }^{56}$ Consistent with accommodations made in UK legislation therefore, the new legislative provisions relating to "Specified Financial Transactions" are not limited to Islamic financial activity; any structures which fall within the provisions will be subject to the same tax framework regardless of whether those transactions comply fully, partially or not at all with the dictates of Islam. ${ }^{57}$ Nevertheless, the Irish Government has explicitly confirmed that the relevant modifications were designed to accommodate Islamic financial activity within Ireland's tax regime. ${ }^{58}$

From the provisions of both the Tax Briefing and the Finance Act, as well as subsequent Government commentary on Islamic finance in Ireland, it is apparent that Ireland has adopted the level playing field approach to accommodation implemented in the UK, ${ }^{59}$ Australia, ${ }^{60}$ Hong Kong, ${ }^{61}$ France, ${ }^{62}$ the USA, ${ }^{63}$ increasingly Malaysia, ${ }^{64}$ and even Pakistan. ${ }^{65}$ Through "equality of treatment between Islamic financial products and their conventional counterparts" therefore, economically, though not necessarily structurally, comparable financial services are given the same chance to compete as genuine counterparts. In practice, Ireland's attempts to accommodate Islamic finance have fallen short of the changes needed to ensure a genuinely level playing field between Islamic and conventional products. Nevertheless, it is clear that Ireland's approach to Islamic financial activity is not one of prioritization or preference, but rather one which simply facilitates Islamic finance activity in Ireland by removing some of the legal obstacles faced by $\operatorname{sharī~}^{-} a h$-compliant structures.

\section{Motivations for Accommodating Islamic Finance in Ireland}

The sector of Ireland's financial market which is targeted by moves to facilitate Islamic finance is not made clear in the Tax Briefing or the Finance Act and both of these instruments outline the tax treatment of products which could be used for both wholesale and retail Islamic finance. Government discussion of Islamic finance in Ireland has also generally focused on the fact that modifications were justified in order to provide a level playing field between Islamic and conventional structures ${ }^{66}$ without outlining why such equality is needed in the first place.

The Department of Finance has, however, outlined "opportunities" for Ireland which may arise as a result of integrating Islamic finance into the Irish legal system: encouraging investment into Ireland in the form of wholesale Islamic financial activity and the establishment of Islamic finance institutions, the provision of ethical investment opportunities for Irish investors, and the opportunity for Muslims to participate in the financial sector in a manner which is consistent with their beliefs. ${ }^{67}$ These perceived benefits for Ireland are comparable to the rationales outlined in some other non-Islamic jurisdictions as the basis for integrating Islamic finance. In the UK, for example, the Government has outlined two objectives motivating the accommodation of Islamic finance. Domestically, a policy of non-exclusion from the financial system has warranted Government consideration of how the economic needs of Muslims, who would otherwise not be able to participate in the conventional system, can be met through the provision of retail products which comply with Islam. As a previous chairman of the UK's Financial Services Authority (FSA) noted in relation to the regulation of Islamic finance: 
It would have been an invidious form of social exclusion for regulation to have prevented the development of financial products which conformed with their religious beliefs, and therefore to have condemned them to a position where their religious beliefs prevented them from accessing financial services. ${ }^{68}$

More broadly, the provision of alternative financial products in the wholesale sector aims at reinforcing London's place as a leading international financial center. ${ }^{69}$ In pursuit of these objectives, a working group was established in 2000 at which the financial community, the Government, Muslims in the UK, and the FSA were represented. ${ }^{70}$ This group acknowledged a number of existing hindrances to the mainstream application of Islamic finance in the UK including taxation and regulatory inequalities, issues of standardization, and a lack of awareness and skills related to Islamic finance. ${ }^{71}$ Since then, there has been a steady stream of legislative measures concerning the regulation and taxation of both Islamic retail and Islamic wholesale financial products.

Similarly, the Australian Government has noted that the accommodation of Islamic finance within Australian laws could provide a mechanism for encouraging wholesale, international investment into the Australian economy and for enabling Muslims in Australia to "access products that may be more consistent with their principles and beliefs", thus potentially fostering greater social inclusion. ${ }^{72}$ Like the UK, Australia has sought to balance its focus in relation to Islamic finance between the wholesale and the retail sectors despite the fact that Muslims make up just over 1.7 per cent of Australia's total population. $^{73}$

Dutch financial authorities have also indicated both external and internal justifications for integrating Islamic finance into the Netherlands' established financial system while stressing the need to ensure satisfactory Government oversight of financial activity. ${ }^{74}$ In order to facilitate meaningful integration of $\operatorname{shar}^{-} \mathrm{a} a$-compliant transactions therefore, the Dutch Central Bank has published a report highlighting the regulatory issues which would be faced by retail and wholesale Islamic finance offered in the Netherlands. ${ }^{75}$

Despite wide reliance by Government authorities on this two-fold justification for facilitating Islamic finance, a number of countries have focused more overtly on the wholesale Islamic finance sector. The Singapore Monetary Authority and the Luxembourg Government, for example, have explicitly noted that their primary motivation for developing an Islamic finance industry is to attract international investment into their respective economies, not to provide sharī $a h$-compliant finance to their domestic Muslim populations. ${ }^{76}$ Consistent with this aim, both countries have concentrated their accommodation efforts on wholesale products such as investment funds and sukük.

In Ireland, the actual effect of the Government's accommodation of Islamic finance will be much more one sided than the range of products outlined in the Tax Briefing and Finance Act would suggest. In reality, most commentators have taken the view that the real ambition of the Irish Government when accommodating Islamic finance transactions is the facilitation of wholesale Islamic finance in Ireland's IFSC. ${ }^{77}$ Although the provisions of the Tax Briefing and Finance Act do not restrict their application solely to wholesale Islamic finance, their immediate effect will certainly be limited to the wholesale market. This arises from the fact that no financial institution offers Islamic retail financing to customers in Ireland, Ireland's modified tax law still does not address some of the key tax problems faced by Islamic retail products and, most significantly, Ireland has not yet dealt with the regulation of Islamic financial activity or issues of consumer protection. ${ }^{78}$ As Islamic products are still subject to Ireland's untailored regulatory regime, the distinctive structure of these products may cause them to fall outside the 
scope of relevant regulatory provisions. This will not only reduce the protection offered to consumers who use Islamic products but, in certain cases, may simply prevent the products from being offered to consumers at all. In order to address a similar regulatory gap in the UK, the FSA has clarified the regulatory treatment of a number of retaillevel Islamic finance instruments ${ }^{79}$ thus creating "a level consumer protection playing field with products designed for similar purposes". ${ }^{80}$

Ireland's focus on wholesale, international Islamic finance opportunities is, to a certain extent, understandable. ${ }^{81}$ Ireland's Muslim population remains small, particularly when compared with the much larger and more established Muslim communities in the UK, France, and Germany. By removing obstacles faced by wholesale Islamic finance under Ireland's established laws, the legal recognition of these financial structures would allow Ireland to diversify its financial system in line with the expanding and potentially lucrative global Islamic finance industry. From the Government's perspective, this could draw capital into the Irish economy by encouraging wholesale Islamic finance activity within Ireland and inward investment from participants who are transacting in accordance with the principles of Islamic finance. ${ }^{82}$ There is, in fact, already evidence of some international Islamic finance in Ireland with an expanding number of Islamic funds domiciled and managed in Ireland following their authorization by the Central Bank. ${ }^{83}$ Commenting on the potential for further wholesale Islamic finance activity in Ireland, the Government has referred to the double tax treaties concluded with Gulf States and the "significant opportunities for investment" 84 which are now available "provided the necessary framework is in place for Islamic financial products". ${ }^{85}$ This deepening of Ireland's financial market would be in line with the objectives of Financial Services Ireland which acknowledge the need to support the international marketing efforts affirming Ireland as a "premier location for international financial service". 86

\section{A Financial Inclusion Fustification for Islamic Retail Finance}

Notwithstanding perceived benefits arising out of wholesale Islamic finance in Ireland, the lack of access to retail-level sharī'ah-compliant financial instruments may need to be reconsidered by taxation and regulatory authorities. A mixed message emerges as regards the potential size of an Islamic retail market in Ireland. In a report on the Finance Act 2010, Ireland's Department of Finance noted that "while there have been some indications that [Ireland's Muslim community] would like to see Islamic mortgages offered by banks, there is no evidence of any strong demand for retail financial products as yet". A subsequent information note on "Islamic Finance in Ireland", also published by the Department of Finance, adopted a somewhat more positive tone, stating that the Muslim community in Ireland has "indicated a demand for Shari'a compliant finance". ${ }^{87}$ It is suggested that there is in fact, a greater interest in Islamic retail finance than the Government has indicated. Anecdotal evidence suggests that Muslims in Ireland are interested in using retail-level Islamic products, particularly in order to meet their real property needs ${ }^{88}$ while an informal study indicates a strong awareness amongst Muslims of the lack of such products in Irish financial institutions. ${ }^{89}$ At small business level too, there appears to be support amongst Muslims for the introduction of Islamic finance with one survey indicating that of the Muslim entrepreneurs in Ireland that were interviewed, 90 per cent saw a domestic need for sharī'ah-compliant financial products. ${ }^{90}$

In the absence of consumer-level Islamic finance in Ireland, some members of the Muslim community are now participating in informal financial arrangements in order 
to avoid conventional banking products which involve prohibited ribā, gharar, maysir, and harām sectors. ${ }^{91}$ It is, however, a problematic development as it indicates that financial activity is being conducted outside the regulated financial system and outside the direct control of the State. Not only could this jeopardize consumer protection, but it could marginalize some Muslims, excluding them from a formal economy which is not reconciled to their needs. The absence of regulation over such activities may also cause financial irregularities and a reduction in Government tax revenue. This concern has been raised in a number of countries with the Dutch Finance Minister, for example, noting that "[d]enial of an actual need [for Islamic finance in the Netherlands] can lead to money-flows running via alternative channels out of the sight of the government". ${ }^{92}$ The development of retail-level Islamic finance in Ireland could therefore increase official oversight of financial activity and may also encourage previously unbanked capital into the banking sector. ${ }^{93}$

\section{A Constitutional fustification for Islamic Retail Finance}

In addition to drawing Muslims into the regulated financial market, Government facilitation of Islamic finance domestically would also, it is suggested, be consistent with Ireland's constitutional protection of freedom of religious practice. A similar justification has been relied on by US authorities with Thomas Baxter, General Counsel and Executive Vice President of the Federal Reserve Bank of New York, noting that "we [the regulators] are striving for a better understanding of the principles and tenets underlying Islamic finance, so we can accommodate the free-exercise of religion and still carry out our secular mandate". ${ }^{94}$ While the Preamble of the Irish Constitution (Bunreacht na hEireann) expressly provides that the People of Ireland subjugate themselves to a specified higher authority viz. "our Divine Lord, Jesus Christ", 95 Article 44 of the document contains provisions protecting the rights of adherents of all religions. These rights have frequently been interpreted by the Irish courts in a manner which prioritizes freedom of religious practice even where it leads to apparently positive discrimination in favor of a particular religion. ${ }^{96}$ The Irish courts have therefore explicitly acknowledged the validity of legislation which seeks to accommodate religious activity.

When justifying this accommodation, the judiciary has adopted an increasingly broad interpretation of the type of practices which will fall within the Article 44 protections. In McNally \& Anor $v$ Ireland $\mathcal{E}$ Ors ${ }^{97}$ for example, Mac Menamin J. appeared to suggest that for Article 44 to apply there would need to be an identifiable religious interest at stake, which is more than marginally important to the activity in question, though not necessarily an essential element of the religion as a whole. ${ }^{98}$ Most recently, Hogan J. noted that it is not for the court to decide what was "orthodox or conventional" in matters of faith and was satisfied that a Jehovah's Witnesses refusal of blood transfusions was "scripturally ordained" and a "test of faith" when such a situation arises. ${ }^{99}$ In light of this case law it is suggested that where religious activity is one which is more than peripheral to the religion and has an identifiable connection with religious faith, then the Government may justifiably accommodate it, even if that activity is not a universally acknowledged manifestation of core religious tenets. Like many of Islam's teachings, ${ }^{100}$ there is not unwavering unanimity over the finer details of Islamic financial transactions. Without a centralized religious authority, such agreement may be difficult to achieve in practice. Nevertheless, there appears to be broad consensus amongst Islamic scholars regarding the religious principles which underpin shari ${ }^{-} a h$-compliant financial transactions with 
the underlying prohibitions which are imposed on such transactions based on specific, textual, references in the Qur'än and Sunnah. ${ }^{101}$ These provisions do not simply catalogue undesirable activity but repeatedly refer to practices which, if engaged in, would theoretically result in punishment in the Hereafter. It is therefore suggested that the act of adhering to these doctrinal tenets forms a practice which is widely considered by Muslims to be motivated by conviction and expressly dictated by the sources of Islam. Even if such practice does not have the overt centrality to religious adherence as, for example, worship, it has nevertheless been repeatedly cited by scholars and commentators as a significant aspect of Islam and a religious principle to be adhered to, save in the case of absolute necessity. ${ }^{102}$

There are, therefore, a number of reasons justifying a more directed effort by the Irish Government to consider how Islamic retail finance can be integrated into Ireland's financial and legal systems. Until such integration is achieved, there remain numerous obstacles stymieing the establishment of a level playing field between Islamic and conventional financial activity. The remainder of this article will consider sharī'ah-compliant mortgage-alternatives and their likely treatment under Irish law. In doing so, it will highlight areas where specific accommodation may be needed.

\section{Shari' ah-Compliant Mortgage-Alternatives}

Conventional mortgages involve the use of real property as security for a loan and thus as a mechanism for ensuring repayment to a bank of the sum originally lent to the borrower, plus the bank's profit. ${ }^{103}$ This assured repayment of principle plus interest violates the contemporary interpretation of the prohibition of rib $\bar{a}$ and gharar as it involves the use of money as a commodity and seeks to guarantee repayment at a date in the future, regardless of intervening events. ${ }^{104}$ As a result of these sharī'ah incompatible aspects of conventional mortgages, market participants who want to conduct their financial activity in accordance with the principles underpinning Islamic finance are excluded from participating in the conventional mortgage market. ${ }^{105}$ This places Muslims in a difficult position as they are prevented from acquiring property unless they can afford to pay the full purchase price immediately.

In order to avoid the prohibited elements of conventional mortgages while still providing Muslims with a mechanism for funding the purchase of property, a number of shari' $a h$-compliant mortgage-alternatives have been developed by contemporary Islamic scholars. These products can be structured either according to a murābaha (sale of the property to the customer with payment on a marked-up basis), ${ }^{106}$ an ijärah wa-iqtina (lease of property to customer followed by an eventual transfer of title), ${ }^{107}$ or a mushāraka mutanaqisah contract (shared ownership of the property between bank and customer, the lease of that property and subsequent transfer of title). ${ }^{108}$ In the $\mathrm{UK}$, all three forms of mortgage-alternative have been accommodated in taxation and regulatory provisions and all three are offered in the financial sector. ${ }^{109}$

In Ireland, protection offered to the consumer in a mortgage can be found in the Consumer Credit Act 1995 (the CCA 1995). ${ }^{110}$ The Act defines a "housing loan" as "an agreement for credit on the security of a mortgage of a freehold or leasehold estate or interest in a house...", 11 and a mortgage is defined as including a charge. ${ }^{112}$ Complying with this definition is relatively straightforward for murābaha based mortgage-alternatives as these structures involve full transfer of the property to the customer who then repays the debt and grants a charge over the property to the bank; in line with the CCA 1995 definition, an agreement for credit and the grant of security are both therefore present. 
Ijārah wa-iqtina and mushāraka mutanaqisah structures raise considerably more difficulties. In both of these arrangements, the financial institution has total or partial ownership of the property for the duration of the transaction and only at the end will full title to the property be transferred to the customer. There is no credit extended by the bank to the customer and only limited opportunity for the customer to grant a charge over the property. ${ }^{113}$ Ownership of the property by the bank therefore creates a relationship with the customer which is not characteristic of a conventional mortgage. As a result, these mortgage-alternatives fall outside of the definition of housing loans in the CCA 1995 and thus the consumer protections and regulatory oversight provided by that legislation. Not only could this lead to confusion amongst participants in relation to their actual and potential rights and responsibilities under these transactions but would result in some Islamic real estate products being subject to regulation which is distinct from that imposed on the conventional mortgages they are designed to substitute.

A similar issue arose in the UK. ${ }^{114}$ In order to ensure comparable regulatory treatment of customers, positive measures were taken by the British Government to bring all shar' ${ }^{`} a h$-compliant mortgage-alternatives within the regulatory remit of the FSA. By extending secondary legislation (primarily the Financial Services and Markets Act 2000 (Regulated Activities) Order 2001 (RAO)), ${ }^{115}$ a new category of regulated activity was created relating to "Home Purchase Plans". ${ }^{116}$ Under section $63 \mathrm{~F}(1)$, the RAO, as amended, now states that "[e]ntering into a regulated home purchase plan as home purchase provider is a specified kind of activity"117 and therefore subject to FSA oversight. Home Purchase Plan is defined as an arrangement under which the borrower is obliged to buy the interest which the home purchase provider (the bank) has in the relevant property over the course of, or at the end of, a specified period. ${ }^{118}$ Such an extension to the secondary legislation brings both ijärah wa-iqtina and mushäraka mutanaqisah products ${ }^{119}$ within the regulatory control of the FSA and ensures that any person seeking to offer an Islamic mortgage-alternative will now require authorization. Finally, in order to ensure a more comparable playing field the FSA's "Mortgage and Home Finance: Conduct of Business Sourcebook" (MCOB) has been amended to provide guiding rules relating to the provision of Islamic mortgage-alternatives. ${ }^{120}$ This has extended the disclosure, charges, treatment of arrears and repossessions and responsible lending ${ }^{121}$ provisions of MCOB to sharī'ah-compliant activity.

These measures highlight the UK's acknowledgement that comprehensive oversight of all mortgage products can only be achieved through tailored regulatory amendments. A similar approach should be taken in Ireland. The reality is that the current regulatory framework in Ireland is simply incapable of providing adequate protection for all varieties of Islamic mortgage-alternative. In order for these structures to benefit from regulatory protection therefore, legislative adjustments must be undertaken. It is suggested that the housing loan provisions of the CCA 1995 should be extended to cover "Housing Loans and Specified Home Purchase Arrangements" 122 in an accommodation which is similar to that adopted in the UK. "Specified Home Purchase Arrangements" could then be defined in a manner which would cover lease-to-own products which are in compliance with Islam. ${ }^{123}$ The remainder of the CCA 1995 would need little adjustment other than terminological modifications as its provisions are relatively consistent with the requirements of Islamic finance. By expanding the consumer protections offered in the CCA 1995 to include "Specified Home Purchase Arrangements", Irish regulatory authorities would be able to provide a comparable level of rights and duties for participants in Islamic transactions as those found in secured property lending. This parity could be achieved without having to undertake comprehensive legislative re-writing and without 
radically undermining the ability of the parties to comply with Islamic law's financial principles.

In the absence of such reform, the regulation of Islamic mortgage-alternatives offered in Ireland remains highly uncertain. However, clarifying the taxation position of "credit transactions", the Finance Act 2010 outlines a number of contracts which encapsulate the structures of murābaha ${ }^{124}$ and mushäraka mutanaqisah ${ }^{125}$ transactions. $^{126}$ In order to establish parity of taxation between conventional financial contracts and these Islamic structures, the Finance Act treats credit transactions as if they establish a loan relationship between bank and customer and it treats the bank's return as if it were interest. Section 267 O Taxes Consolidation Act 1997, as amended by the Finance Act, therefore provides that the credit return arising out of the different forms of credit transaction is, for the purpose of the Tax Acts, treated as if it were interest on a loan. ${ }^{127}$ Effectively the Finance Act seeks to bring these arrangements within the scope of the existing rules applying to loans and interest, where the structural distinctiveness of Islamic financial activity would otherwise have led to anomalous tax results. For Muslims in Ireland who wish to purchase property using one of these structures, the returns paid to the bank will now be taxed and relieved as if they were interest payments made on a conventional mortgage. This is an important development for retail-level Islamic finance in Ireland and it reflects similar adjustments made in the UK.

There remain, however, a number of obstacles preventing a truly level playing field in terms of the taxation of Islamic mortgage-alternatives. Principal amongst these is the multiple stamp duty liability which arises in relation to all forms of Islamic mortgagealternative. For these arrangements to be legitimate under shari' $a h$, ownership of the property must pass from the original seller, to the bank and then ultimately to the customer. ${ }^{128}$ The two-fold transfer will result in a double imposition of stamp duty; once when the financial institution acquires ownership and then again when that ownership is ultimately transferred in whole to the borrower. ${ }^{129}$ Additional taxation will inevitably affect the competitiveness of shari $a h$-compliant financings, yet the Finance Act has made no attempt to address this. Even the subsequent Guidance Notes issued by the Revenue Commissioners, while referring to the stamp duty issue, reiterate that "stamp duty will arise under normal rules". ${ }^{130}$

Identifying the points at which the first and second transactions take place and limiting the imposition of stamp duty to only one, the stamp duty issue arising in relation to Islamic property transactions was the first taxation inequality to be addressed by Her Majesty's Revenue and Customs (HMRC) in the UK. Section 72 of the Finance Act 2003 eliminated double Stamp Duty Land Tax (SDLT) in relation to murabaha transactions $^{131}$ and a similar carve-out was inserted for mushāraka mutanaqisah and ijārah wa-iqtina in $2005 .{ }^{132}$ While these amendments have subsequently required adjustments in order to minimize the potential for tax avoidance, the elimination of double stamp duty liability has removed a considerable stumbling block in the way of creating an effective Islamic retail finance market in the UK. ${ }^{133}$ In light of the Irish Finance Act's attempt to alleviate other tax burdens experienced by Islamic financial transactions, it is disappointing that it failed to address the outstanding stamp duty issue.

\section{Conclusion}

Commenting on Islamic finance in the USA, one commentator has noted that "the legal changes necessary to implement an Islamic finance system do not require wholesale reorganization of private law or even commercial law". ${ }^{134}$ If one considers the precedent set in 
the UK, this contention appears to be largely correct; the integration of Islamic finance does not necessitate the establishment of an entirely separate, bespoke legal regime for religiously guided finance. However, in light of the structural distinctiveness of Islamic financial activity, a Government cannot adopt a non-interventionist, passive approach to integration while still expecting Islamic finance to develop into a viable segment of the national economy. If Islamic products are to compete with their conventional counterparts on a level playing field therefore, it will be necessary to expand existing legislative provisions so as to accommodate Islamic structures and to clarify their legal treatment. Without this, Islamic finance products could be taxed and regulated in a manner which is inconsistent not only with their economic substance but also with the treatment of comparable interest-based transactions.

The Tax Briefing 2009 and the relevant provisions of the Finance Act 2010 go some way towards establishing this level playing field for Islamic finance within Ireland's financial market. However, the impact of such accommodations will primarily be felt in the wholesale sector. This situation has arisen as a result of the fact that retail-level Islamic finance has not yet been made available to Irish consumers despite calls from the Muslim community for its introduction as well as the constitutional basis justifying the accommodation of Islamic financial activity. Due to remaining issues relating to taxation of Islamic retail products and the inability of Ireland's regulatory regime to ensure the equal treatment of these structures, Islamic retail finance in Ireland continues to face numerous burdens. In the absence of amendment to Ireland's regulatory legislation and further modification of the tax regime, these burdens will remain, thus hindering the emergence and development of domestic Islamic finance activity.

While there may be valid reasons why the Irish Government should move to accommodate both wholesale and retail Islamic structures however, the extent to which financial institutions will be willing to offer Islamic products to Irish consumers is uncertain. While the Muslim population in Ireland is growing rapidly, it remains small both in absolute terms and as a percentage of Ireland's population; too small perhaps for a financial institution to justify the expense associated with introducing new financial products. Nevertheless, it is suggested that Ireland's small Muslim population should not prevent the Government from effectively accommodating retail Islamic products within Irish legislation. Such accommodations would simply extend the range of financial services which may be provided in Ireland rather than force financial institutions to offer Islamic products. As a result, legislative obstacles which would otherwise have been faced by any financial institution and consumer attempting to enter into an Islamic retail finance transaction would be removed. This may encourage Irish banks to develop Islamic financial products designed for an expanding Irish market.

\section{Acknowledgements}

The author would like to thank Marian Richardson and Joseph Harrington for reading and commenting upon an earlier draft of this article and the Irish Research Council for Humanities and Social Science for providing funding to undertake the research on which this article is based.

\section{NOTES}

1. "Islamic finance" will be used throughout the article to refer to both Islamic banking and Islamic finance. 
2. The first successful attempt at contemporary Islamic finance began in rural Egypt in Mit Ghamr and Dondait in 1963. See, Abdelkader Chachi, "Origin and Development of Commercial and Islamic Banking Operations", fournal of King Abdulaziz University: Islamic Economics, Vol. 18, No. 2, 2005, pp. 3-25. The industry has now spread outside of traditional Islamic markets and into Europe, the USA, and Australia. See also, Bill Maurer, "Re-formatting the economy. Islamic banking and finance in world politics", in Islam in World Politics, eds. Nelly Lahoud and Anthony H. Johns, London: Routledge, 2005, pp. 54-66, see p. 55.

3. France for example has restricted certain overt signs of adherence to Islam (Justin Vaïsse, "Veiled Meaning: The French Law Banning Religious Symbols in Public Schools". US-France Analysis Series. The Brookings Institution, 2004) while concurrently publishing tax rules which clarify the tax treatment of certain Islamic finance products and ensure their tax neutrality with conventional financial products, Michael Mahlknecht and Kabir Hassan, Islamic Capital Markets: Products and Strategies, Chinchester: John Wiley \& Sons, 2011, p. 347.

4. As Khan noted "The resurgence in interest in Islamic conservatism is a result of a long prevailing identity crisis being experienced by Muslims. The self-pride of Muslims that came from having been conquerors and rulers for over a millennium was battered by the shocking reality of Western military and technological superiority". See Shahrukh Rafi Khan, Profit and Loss Sharing: An Islamic Experiment in Finance and Banking, Oxford: Oxford University Press, 1987, p. 7.

5. Even the Vatican has voiced support for Islamic finance when it noted that the "[e]thical principles on which Islamic finance is based may bring banks closer to their clients and to the true spirit which should mark every financial service". Loretta Napoleoni and Claudia Segre, "Dalla finanza islamica proposte e idee per l'Occidente in crisis" (Islamic Finance proposals and ideas for the west in crisis), l'Osservatore Romano, March 4 2009, accessed May 14 2011, http://rassegnastampa.mef.gov.it/ mefnazionale/PDF/2009/2009-03-04/2009030412006886.pdf. Original Italian text translation into English, Adrienne Strubb.

6. Mohammed El Qorchi, "Islamic Finance Gears Up", Finance \& Development, Vol. 42, No. 4, December 2005, accessed 14 May 2011, http://www.imf.org/external/pubs/ft/fandd/2005/12/ qorchi.htm.

7. Frederik Richter, "Islamic finance assets seen at $\$ 1.6$ trln by 2012", Reuters, April 82009 , accessed May 14 2011, http://www.reuters.com/article/2009/04/08/islamicfinance-growth-idUSL8943290 20090408.

8. The Irish Revenue Commissioners, "Islamic Finance", Tax Briefing Issue 78, October 2009, accessed May 14 2011, http://www.revenue.ie/en/practitioner/tax-briefing/78/index.html\#.

9. Finance Act 2010 (Irl) (Number 5 of 2010).

10. Islamic countries continue to represent a large market for Islamic financial activity, however Western economies, particularly the UK and Luxembourg, have emerged as important centers for shari ${ }^{-} a h$ compliant transactions. Robert Toan, "Cross-Border Ijarah; A Case study in the US Taxation of Islamic Finance", in Third Harvard Islamic Proceedings, Cambridge: Harvard Islamic Finance Program, 2000, pp. 191-197.

11. See for example, Bill Maurer, "Faith in the Form: Islamic Home Financing and 'American' Islamic Law", in Being and Belonging: Muslims in the United States since 9/11, ed. Katherine Ewing, New York: Russell Sage Press, 2008, pp. 178-199: Rodney Wilson, "Islamic Banking in the United Kingdom", in Islamic Banking and Finance in the European Union: A Challenge, eds. M. Fahim Khan and Mario Porzio. Cheltenham: Edward Elgar, 2010, pp. 212-221.

12. Islamic finance is not restricted in its availability only to Muslims. In theory anyone, regardless of faith, can use these products. For the purpose of this article however, the focus of discussion will primarily be on Muslims in Ireland.

13. Qur'ān 2:275, all references to the Qur'ān are from Muhammad Taqi-ud Din Al-Hilali and Muhammad Muhsin Khan, tr., Interpretation of the Meanings of the Noble Qur'an in the English Language, Riyad: Maktba Dar us-Salam, 1996. Imtiaz Pervez, "Islamic Finance", Arab Law Quarterly, Vol. 5, No. 4, 1990, p. 259. Economic issues are dealt with extensively by the figh writers who have expanded greatly on application of Shari ${ }^{-} a h$ principles in the commercial world as well as provided commentary on how Islam's basic tenets can be most faithfully applied in commercial dealings.

14. Qur'ān 2:274.

15. Muhammad Ayub, Understanding Islamic Finance, Chinchester: John Wiley \& Sons, 2007, p. 43.

16. Qur'ān 2:275.

17. Hjh Siti Faridah Abd Jabbar, "Islamic Finance: Fundamental Principles and Key Financial Institutions", Company Lawyer, Vol. 30, No. 1, 2009, pp. 23-32, see p. 24. 
18. Islamic Fiqh Academy declared in 1985 that all interest-bearing transactions were prohibited and void. The Council of the Islamic Fiqh Academy, Resolution No10 (10/2); "Concerning Transactions with Banks Dealing with Interest and Transactions with Islamic Banks”, 2nd session, 22-28 December 1985, p. 15; Daniel Klein, "The Islamic and Jewish Laws of Usury: A Bridge to Commercial Growth and Peace in the Middle East”, Denver Fournal of International Law and Policy, Vol. 23, 1994-1995, pp. 535-554, see p. 538.

19. Sohail Jaffer, Islamic Retail Banking and Finance: Global Challenges and Opportunities, London: Euromoney Books, 2005, p. 123.

20. Rodney Wilson, "The Issue of Interest and the Islamic Financing Alternatives", fournal of International Banking Law, Vol. 13, No. 1, 1997, pp. 23-29, see p.23.

21. Andrew Henderson, "Limiting the Regulation of Islamic Finance: Lessons from Dubai", Clifford Chance, March 2009, accessed May 14 2011, http://www.cliffordchance.com/showimage/ showimage.aspx?LangID=DE\&binaryname $=/$ httpsonlineservicescliffordchancecomonlineviewcont entactioncontentid2084370channelid7.pdf.

22. Qur'ān, 5:90-91, “O, you who believe! Intoxicants (all kinds of alcoholic drinks), and gambling... are an abomination of Satan's handiwork. So avoid that (abomination) in order that you may be successful".

23. Noor Mohammed, "Principles of Islamic Contract Law", fournal of Law and Religion, Vol. 6, No. 1, 1988, pp. 115-130, see p. 121.

24. Qur'ān, 5:90-91.

25. As a result, conventional futures contracts are widely prohibited since they are based on speculation in the future movement of prices. Tala DeLorenzo, "The Religious Foundations of Islamic Finance", in Islamic Finance, Innovation and Growth, ed. Simon Archer and Rifaat Abdel Karim, London: Euromoney Books, 2002, pp. 22-23.

26. Rodney Wilson, "The Issue of Interest and the Islamic Financing Alternatives”, op. cit., p. 25.

27. Anne E. Mayer, "The Regulation of Interest Charges and Risk Contracts: Some Problems of Recent Libyan Legislation", The International and Comparative Law Quarterly, Vol. 28, 1979, pp. 541-559, see p. 554; Abdullah Yusuf Ali, The Holy Qur'ān: Text, Translation and Commentary, Washington, DC: The American International Printing Company, 1946, p. 86, footnote 241.

28. Angelo M. Venardos, Islamic Banking and Finance in South-East Asia: Its Development and Future, 2nd edn, Singapore: World Scientific Publishing Co., 2007, p. 54.

29. Noor Mohammed, "Principles of Islamic Contract Law", op. cit., p. 120; Nabil Saleh, Unlawful Gain and Legitimate Profit in Islamic Law, Cambridge: Cambridge University Press, 1986, p. 62.

30. Hjh Siti Faridah Abd Jabbar, "Islamic finance: fundamental principles and key financial institutions", op. cit., p. 24.

31. See generally, Yusuf al-Qaradawi, The Lawful and the Prohibited in Islam, trans. Kamal El-Helbawy, M. Moinuddin Siddiqui, and Syed Shukry, London; Al-Birr Foundation, 2003.

32. For example, the Qur'anic prohibition of pork; "He hath forbidden you only carrion, and blood, and the flesh of swine, and that which is slaughtered as a sacrifice for others than Allah... But if one is forced by necessity without wilful disobedience nor transgressing due limits, the there is no sin on him...". Qur'ān 2:173.

33. "When Allah prohibits a thing, He prohibits [giving and receiving] the price of it as well", Musnad Ahmad ibn Hanbal, Hadith no. 2546, quoted in Yusuf Al-Qardawi, The Lawful and the Prohibited in Islam, 2nd edn, Al-Falah Foundation for Translation, Publication \& Distribution, Cairo, 2001, p. 252.

34. M. Umer Chapra, "Islam and the Economic Challenge", Islamic Economics Series, Vol. 17, Markfield: The Islamic Foundation, 2003, p. 59.

35. Ibid., p. 75.

36. Thomas Philipp, "The Idea of Islamic Economics", Die Welt des Islams, Vol. 30, 1990, pp. 117-139, see p. 124.

37. Sayed Qutb, Social fustice in Islam, Washington, DC: American Council of Learned Societies, 1953, p. 248. See generally Charles Tripp, Islam and the Moral Economy: The Challenge of Capitalism, Cambridge: Cambridge University Press, 2006, p. 150 et seq.

38. Mehmet Asutay, "Conceptualisation of the Second Best Solution in Overcoming the Social Failure of Islamic Banking and Finance: Examining the Overpowering of Homoislamicus by Homoeconomicus", IIUM fournal of Economics and Management, Vol. 15, No. 2, 2007, pp. 167-195.

39. Charles Tripp, Islam and the Moral Economy, op. cit., pp. 141-142, see also, Goolam Vahed and Shahid Vawda, "The Viability of Islamic Banking and Finance in a Capitalist Economy: A South 
African Case Study", fournal of Muslim Minority Affairs, Vol. 28, No. 3, December 2008, pp. 453472 .

40. "Census 2006, A Census of Population was taken on the night of Sunday, 23 April 2006", Principal Demographic Results, Irish Central Statistics Office, accessed May 14, 2011, http://www.cso.ie/census/ documents/Amended\%20Final\%20Principal\%20Demographic\%20Results\%202006.pdf.

41. Nominate contracts represent the various different contractual forms developed by the classical Islamic scholars as mechanisms through which Muslims could conduct financial activity without violating the teachings of Islam, see generally, Frank Vogel and Samuel Hayes III, Islamic Law and Finance: Religion, Risk, and Return, The Hague: Kluwer Law International, 1998, p. 102 et. seq.

42. Mohammed, "Principles of Islamic Contract Law", op. cit., p.123.

43. Michael J. T. McMillen, "Shari'a-Compliant Project Finance: A Structural Overview", in The Chancellor Guide to the Legal Shari'a Aspects of Islamic Finance, eds. Humayon Dar and Umar Moghul, London: Chancellor Publications, 2009, pp. 175-228, see p. 192.

44. Mahmoud A. El-Gamal, Islamic Finance: Law, Economics, and Practice, Cambridge: Cambridge University Press, 2006, p. 18; Yusuf Talal DeLorenzo, "Shariah Boards and Modern Islamic Finance: From the Jurisprudence of Revival and Recovery to the Jurisprudence of Transformation and Adaptation", paper presented at the IFSB Conference, London, May 2004.

45. Yusuf Talal DeLorenzo, "Introduction to Understanding riba", in Interest in Islamic Economics: Understanding riba, ed. Abdulkader S. Thomas, Oxford: Routledge, 2006, pp. 1-9, see p. 6. A feature which, though often used as a justification for questioning the shari' $a h$ legitimacy of these products is, in reality, almost inevitable in light of the fact that these transactions attempt to perform the same basic functions as those found in conventional economies. While this tendency towards emulation of the conventional sector has been the subject of considerable debate, arguments for and against the current state of Islamic finance are beyond the scope of this article.

46. Jonathan Ercanbrack, "The Regulation of Islamic Finance in the United Kingdom", Ecclesiastical Law fournal, Vol. 13, 2011, pp. 69-77, see p. 70.

47. Darko Hajdukovic, "London acts as global gateway for Islamic Finance", in The 2008 Guide to Opportunities $\mathcal{E}$ Trends in Islamic Finance, ed. Sarah Minns, London: Euromoney Research Guides, 2008, p. 6.

48. Howard Davies, "Islamic Finance in the United Kingdom: Current Initiatives And Challenges", speech given at the LSE-Harvard Public Lecture on Islamic Finance, London School of Economics, London, UK, February 26, 2009.

49. David Williams, "The Last Word", Islamic Banking \& Finance, Vol. 7, No. 21, 2009, p. 30; Clive Briault, "London: Centre of Islamic Finance?", speech given at the FSA Industry Forum, London, October 17, 2007, accessed May 14 2011, http://www.fsa.gov.uk/pages/Library/ Communication/Speeches/2007/1018_cb.shtml.

50. Financial Services Authority, "Islamic Banking in the UK", Briefing Note BN016/06. London, March 9, 2006, accessed May 142011 http://www.fsa.gov.uk/pages/About/Media/notes/bn016.shtml.

51. Howard Davies, "Islamic Finance in the United Kingdom: Current Initiatives and Challenges", op. cit.

52. The Irish Revenue Commissioners, "Islamic Finance", op. cit.

53. Department of Finance, "Publication of Finance Act", Press Release, Dublin, February 4, 2010, accessed May $142011 \mathrm{http}$ //www.finance.gov.ie/viewdoc.asp?DocID=6189, noting that the aim of the provisions was to increase the "attraction of Ireland for the development of Islamic finance".

54. s39 and s137 of the Finance Act 2010 (Irl) insert into the Taxes Consolidation Act (TCA) (Irl) 1997 two new provisions, Part $8 \mathrm{~A}$ and $\mathrm{s} 85 \mathrm{~A}$, respectively.

55. Defined in Part $8 \mathrm{~A}$ as meaning a "credit transaction", a "deposit transaction", or an "investment transaction".

56. It provides, for example, for "credit return" and "credit transactions" rather than referring explicitly to the Islamic nominate contracts, section 2670 Taxes Consolidation Act 1997 as introduced by section 39 Finance Act 2010.

57. Irish Revenue Commissioners, "Guidance Notes on the Tax Treatment of Islamic Financial Transactions", Dublin, October 2010, p. 6, accessed May 14, 2011, http;//www.revenue.ie/en/practitioner/ tech.../guidance-notes-islamic-finance.pdf, noting that; "[a]lthough designed to cover certain Shari'a compliant structures, the legislation applies to any financing arrangement falling within the meaning of the term "specified financial transaction" regardless of whether the arrangement is, in fact, Shari'a compliant”.

58. Department of Finance, "Publication of Finance Act", op. cit. 
59. Howard Davies, "Islamic Finance and the UK Financial Services Authority", Speech given at the Bahrain Monetary Authority Conference on Islamic Banking and Finance, Bahrain, March 2, 2003, accessed May 14, 2011, http://www.fsa.gov.uk/Pages/Library/Communication/Speeches/ 2003/sp118.shtml. Ed Balls, "Summit on Islamic Finance”, HM Treasury Press Release, 46/07, April 16 2007, accessed May 14, 2011, http://www.hm-treasury.gov.uk/press_46_07.htm.

60. Nick Sherry, "The Future of Islamic Finance in Australia", speech given at the Islamic Finance Conference Rendezvous Hotel, Melbourne, June 8, 2010. See also, Chris Bowen, Interview with Alex Symonds, Sky Business, January 15, 2010, accessed May 14, 2011, http://www.treasurer.gov.au/ DisplayDocs.aspx?doc $=$ transcripts $/ 2010 / 003 . \mathrm{htm} \&$ pageID $=004 \& \mathrm{~min}=$ ceba\&Year=\&Doc Type $=2$.

61. Ka Keung Chan, "Islamic Finance", speech given at the Islamic Banking and Finance Forum: The Way Forward for the Hong Kong SAR, The Hong Kong Polytechnic University, Hong Kong, May 19, 2008, accessed May 14, 2011, http://www.fstb.gov.hk/eng/sfst/speeches/2008/sp20080519_e. pdf.

62. See for example, Bulletin Officiel des Impôts, (Official Tax Bulletin), No 78 (2010), 4 FE/S1/10 (dealing with murabaha), $4 \mathrm{FE} / \mathrm{S} 2 / 10$ (sukuk), $4 \mathrm{FE} / \mathrm{S} 3 / 10$ (ijarah), and $4 \mathrm{FE} / \mathrm{S} 4 / 10$ (istisna).

63. Scott Schmith, "Trends in Islamic-Finance Regulation", International Trade Administration, US Department of Commerce, 2008, accessed May 14, 2011, http://www.ita.doc.gov/td/finance/ publications/Islamic_Regulatory_2008.pdf.

64. Tan Sri Dato' Sri Dr. Zeti Akhtar Aziz, “Approaches to Regulation of Islamic Financial Services Industry", speech given at the IFSB Summit - Islamic Financial Services Industry and The Global Regulatory Environment, London, May 18, 2004, accessed May 14, 2011, http://www. bnm.gov.my/index.php?ch=9\&pg=15\&ac $=151 \&$ print $=1$.

65. Shamshad Akhtar, "Islamic Finance- Growth, Competitiveness and Sustainability", speech given at the $14^{\text {th }}$ World Islamic Banking Conference Bahrain, 9-10 December 2007, accessed May 14, 2011, http://www.sbp.org.pk/about/speech/governors/dr.shamshad/2007/Growth-Sustainability-9-10Dec-07.pdf.

66. Irish Revenue Commissioners, "Guidance Notes on the Tax Treatment of Islamic Financial Transactions", op. cit., p. 7.

67. Irish Department of Finance, Islamic Finance in Ireland: An Information Note, Dublin: Department of Finance 2010, p. 4.

68. Callum McCarthy, "Regulation and Islamic Finance", speech given at the Muslim Council of Britain Islamic Finance and Trade Conference, June 13, 2006.

69. HM Treasury, "The Development of Islamic Finance in the UK: The Government's Perspective", London: HM Treasury, 2008, p. 13.

70. Michael Ainley et al., "Islamic Finance in the UK: Regulation and Challenges", London: Financial Services Authority, 2007, p. 8.

71. HM Treasury, "The Development of Islamic Finance in the UK: The Government's Perspective", op. cit., p. 15.

72. Nick Sherry, "The Future of Islamic Finance in Australia", op. cit.

73. 2006 Census of Population and Housing, Australian Bureau of Statistics: Australia, 2006, see also, Department of Immigration and Citizenship, The People of Australia, Statistics from the 2006 Census, Australia: Commonwealth Copyright Administration, 2008, Table 12, p. 46.

74. Wouter Bos quoted in "Finance Minister to Encourage Islamic Banking", NIS News Bulletin, July 17, 2007, accessed May 14, 2011, http:/www.nisnews.nl/public/170707_1.htm.

75. Natalie Schoon, "Islamic Finance in Continental Europe", Islamic Finance News, Vo, 6, No. 9, 2009, pp. 14-15. There remain however certain taxation hurdles for Islamic finance in the Netherlands. Niels Muller and Kees Hooft, "Cross Border Islamic Finance in The Netherlands", Islamic Finance News, Vol. 7, No. 47, November 24, 2010, pp. 14-15.

76. Ong Chong Tee, "Singapore's Perspective on Islamic Finance", speech given at the Asian Banker Summit 2005, March 16, 2005, Luxembourg for Finance, "Luxembourg Vehicles for Islamic Finance Structures”, Luxembourg: Agency for the Development of the Financial Centre, 2010.

77. See, for example, Ken Owens, Enda Faughnan, Yvonne Thompson and Omer Khan, "Ireland's New Finance Bill”, Dublin: Price Waterhouse Coopers, 2010. See also comments made at The Irish Banking Federation, Islamic Finance Seminar, Dublin, June 2010.

78. Department of Finance, "Section 1 of Finance Act 2010, Report on Tax Expenditures", PRN A10/ 0776, July 2010, accessed May 14, 2011, http://www.finance.gov.ie/documents/.../reports/2010/ taxexpenditure.pdf. 
79. See for example, MCOB 1.2.1R, J. Patient, "Islamic Finance in the UK Consumer Sector", fournal of International Banking Law and Regulation, Vol. 23, 2003, p. 9, Andrew Henderson, "Islamic Financial Services", in Financial Services Law, edited by Michael Blair, George Walker and Robert Purves, 2nd edn, Oxford: Oxford University Press, 2009, pp. 979-1026, see p. 1022.

80. Dan Waters, quoted in the Financial Services Authority, "Home reversions and Islamic Mortgages Get New Consumer Protections”, Press Release, FSA/PN041/2006, April 27, 2006, accessed May 14, 2011, http://www.fsa.gov.uk/pages/Library/Communication/PR/2006/041.shtml.

81. And indeed, not uncommon, Hans Peters, "Islamic Finance Needs Retail Push: Ernst \& Young", Reuters, February 18, 2010.

82. Irish Department of Finance, Islamic Finance in Ireland; An Information Note, op. cit. See also, Brian Lenihan, Comments made at Dáil Eireann Debate, Vol. 704, No. 4, Finance Bill 2010: Report Stage (Resumed) and Final Stage, Dublin: Houses of the Oireachtas, March 10, 2010.

83. For example; Oasis Crescent Global Equity Fund, DWS Noor Islamic Funds plc, SEI Islamic Investments Fund plc, The Concord Islamic US Equities Fund and The SEI Islamic US Equity Fund.

84. Irish Department of Finance, Islamic Finance in Ireland; An Information Note, op. cit., p. 4.

85. Ibid.

86. Financial Services Ireland, Objectives, accessed May 14, 2011, http://www.fsi.ie/sectors/fsia/ fsiDoclib3.nsf/vLookupHTML/About_Us_Objectives?OpenDocument.

87. Irish Department of Finance, Islamic Finance in Ireland; An Information Note. op. cit., p. 4.

88. Interview with Ali Selim, former Secretary of the Irish Council of Imams, conducted at Clonskeagh Mosque, March $20^{\text {th }}, 2010$. See also, Mary Fitzgerald, "Call for Sharia-compliant Finance Services in Ireland", The Irish Time, May 30, 2008.

89. Vivian Ibrahim, and Edana Richardson, UCC Project Survey, conducted as part of "The history of Islam in Ireland" project at University College Cork, April 2010.

90. Fiona Gartland, "Muslim Entrepreneurs Need Access to Sharia-friendly Financial Products", The Irish Times, October 7, 2010.

91. An interview with a member of the Muslim community, Shahzad Ahmed, conducted in March 2011 indicated the use of an informal co-operative model of financing in which each member contributes money to a pool and that pool is then paid over to one member of the group with each member eventually being paid. Thus, financing can be obtained without the payment of interest.

92. Wouter Bos, quoted in "Finance Minister to Encourage Islamic Banking", op. cit.

93. Albrecht Matuschka, "Islamic Sustainable Finance: Creating Faith-Based Value", Business Islamica, December 2007, pp. 78-80, see p. 79.

94. Thomas C. Baxter, "Regulation of Islamic Financial Services in the United States", speech given at the Seminar on Legal Issues in Islamic Financial Services Industry, March 2, 2005, accessed May 14, 2011, http://nubank.com/islamic/ROIF.pdf. See also Kettell who notes that " $[\mathrm{t}]$ he West needs to understand Islamic finance because such an understanding is necessary to implement one of its own core values. The core value is freedom of religion... To foster banking and financial market integrity we need to see whether Western practices may be changed to accommodate and learn from those of the Muslim faith", Brian Kettell, "The Last Word", Islamic Banking \& Finance, Vol. 6, Issue 2, No. 17, 2008, pp. 29-30, see p. 29.

95. Preamble, Bunreacht na hÉreann, 1937.

96. Quinn's Supermarket v. Attorney General [1972] IR 1, per Walsh J., see also, McGrath v Maynooth College [1979] I.L.R.M. 166 and Mulloy v. Minister for Education in which J. Walsh confirmed his earlier ruling, noting that discrimination on the basis of religion is impermissible "save where it is necessary to do so for the implementation of the constitutional right to the full and free practice of religion”. Mulloy v. Minister for Education [1975] IR 88, p. 96.

97. McNally \& Anor v Ireland $\mathcal{E}$ Ors [2009] IEHC 573.

98. McNally $\mathcal{E}$ Anor v Ireland $\mathcal{E}$ Ors [2009] IEHC 573, [140]-[171].

99. Temple Street $v$ D. E Anor [2011] IEHC 1, [28].

100. Werner Menski, "Accommodating Religious Needs in Relation to Marriage: Flying Kites and Navigating State Law and Other Forms of Law", Stato, chiese e pluralismo confessionale, (State, churches and confessional pluralism), 2008, 1-25, p. 8.

101. H. Patrick Glenn, Legal Traditions of the World, 3rd edn, Oxford: Oxford University Press, 2007, p. 202, Noel James Coulson, A History of Islamic Law, Edinburgh: Edinburgh University Press, 1964, pp. 38-39 both of whom highlight the doctrinal basis of Islamic economic principles. 
102. The European Council for Fatwa and Research (ECFR) concluded that as a result of the principles of necessity (darura) and need (haja), Muslims living in a non-Muslim country could use a conventional loan to acquire their home where they had no other reasonable choice, European Council for Fatwa and Research, "Resolution 2/4: Purchasing houses with an usurious loan for Muslims living in non-Muslim countries, i.e. taking up a mortgage to buy a house", Dublin, 1999, accessed May 14, 2011, http://www.globalwebpost.com/farooqm/study_res/i_econ_fin/ecfr-fatwa_mortgage.htm. The fatwa was, however, the subject to considerable backlash, for example, Shaykh Mahmud b. Rida Murad in Saudia Arabia stated that "by allowing usury, [the ECFR] permitting Muslims in the West to fornicate, to consume alcohol and to commit all sorts of sins, since its reasoning allows all difficulties to be removed". Da'wa, December 12, 1999 quoted in Alexandre Caeiro, "The Social Construction of Shari'a: Bank Interest, Home Purchase, and Islamic Norms in the West", Die Welt des Islams, Vol. 44, No. 3, 2004, pp. 349-375, see p. 365.

103. Bill Maurer, Pious Property; Islamic Mortgages in the United States, New York: Russell Sage Foundation, 2006, pp. 18-19.

104. Jennifer Murray, "Of Note: Home Ownership the Islamic Way: Sharia-Compliant Mortgages in the United States”, SAIS Review, Vol. 27, No. 2, Summer-Fall 2007, pp. 93-94, see p. 93.

105. Carolyn Said, "A Means to a Home: Islamic Co-ops Create Happy Homecomings", San Francisco Chronicle, November 1, 2006, p. C1; Roberta Mann, "Is Sharif's Castle Deductible?: Islam and the Tax Treatment of Mortgage Debt”, William \& Mary Bill of Rights fournal, Vol. 17, 2009, pp. 1139-1169, see p. 1147.

106. Under the murabaha method, the financier buys the property and sells it immediately to the borrower for the original purchase price plus an agreed mark-up (the financier's profit) to be paid in installments.

107. Under the ijarāh wa-iqtina model, the borrower undertakes to purchase the property at the end of the rental period with the purchase price spread out over the duration of the lease- the bank remains owner of the property for the lease term and the rent paid by the borrower represents the banks profit, H. A. Dar, "Islamic House Financing in the United Kingdom: Problems, Challenges and Prospects", Review of Islamic Economics, Vol. 12, 2002, p. 47, see p. 51.

108. Under mushäraka mutanaqisah model, the financier and the customer enter into a joint ownership of a property, the financier leases its share back to the borrower who also progressively purchases the financier's equity in the property until the financiers share in the property is reduced to zero. Michael Ainley et al., Islamic Finance in the UK: Regulation and Challenges, op. cit., p. 20.

109. Although it has been suggested that there is a preference for ijarāh wa-iqtina and mushāraka mutanaqisah, Michael Ainley et al., Islamic Finance in the UK: Regulation and Challenges, op. cit., p. 20.

110. Consumer Credit Act, 1995, (Irl) No. 24/1995.

111. Consumer Credit Act, 1995, (Irl), Interpretation

112. Section 2(1) Consumer Credit Act, 1995, (Irl) as substituted by section 33 of, and Part 12 of Schedule 3 to, the Central Bank and Financial Services Authority of Ireland Act 2004 (Irl).

113. Secretary of State for Work and Pensions v UP [2010] UKUT 262 (AAC), [3].

114. Regulatory oversight only extended to cover "regulated mortgages". Under the FSA's definition of a regulated mortgage contract "a lender provides credit to an individual... and the obligation of the borrower to repay is secured by a first legal mortgage on land in the United Kingdom, at least $40 \%$ of which is used, or is intended to be used, as or in connection with a dwelling by the borrower". The Financial Services and Markets Act 2000 (Regulated Activities) Order 2001 (RAO), 2001, (UK), Statutory Instrument 2001 No. 544, Chapter XV, Regulated Mortgage Contracts.

115. Amendments were also made to the Terrorism Act 2000, (UK), the Proceeds of Crime Act 2002 (UK), and The Financial Services and Markets Act 2000 (Financial Promotions) Order 2005 (UK).

116. Financial Services Authority, Regulation of Home Reversion and Home Purchase Plans, London: FSA, 2006, p. 6.

117. Section63F(1) Financial Services and Markets Act 2000 (Regulated Activities) Order 2001 (UK).

118. Section63F(3)(iii) Financial Services and Markets Act 2000 (Regulated Activities) Order 2001 (UK).

119. Much of the documentation relating to these modifications refers only to ijarah mortgages. However, diminishing musharakah mortgages are equally likely to fall within this definition, a fact acknowledged by the government when it noted that "generally references to Ijarah products should be taken to include diminishing Musharakah products". HM Treasury, Secondary Legislation for the Regulation of Home Reversion and Home Purchase Plans: A Response to the Government Consultation. London: HM Treasury, 2006, p. 1. 
120. MCOB 1.2.1 (1) noting that: "This sourcebook applies to every firm that: (a) carries on a home finance activity (subject to the business loan application provisions); or (b) communicates or approves a financial promotion of qualifying credit, of a home purchase plan or of a home reversion plan". (emphasis added).

121. MCOB 4.10 (advertising and selling standards), MCOB 5.8 (pre-application disclosure), MCOB 6.8 (Disclosure at the offer stage), MCOB 7.8 (Disclosure at start of contract and after sale), MCOB 11 (Responsible lending and responsible financing of home purchase plans), MCOB 12.7 (Charges), MCOB 13.8 (Arrears and repossessions).

122. Or some variation on this terminology.

123. This would cover both ijarāh wa-iqtina and mushāraka mutanaqisah products.

124. Paragraph (a), definition of "credit transaction", section 267(1) TCA 1997 as inserted by section 39 Finance Act 2010 (Irl),

(a) an arrangement whereby a finance undertaking acquires an asset for the purpose of disposing of the full interest in that asset to a borrower in circumstances where:

i. the consideration paid or payable by the borrower exceeds the consideration paid or payable by the finance undertaking for the asset,

ii. all or part of that consideration is not required to be paid until a date later than the date of the disposal, and

iii. the excess of the consideration paid or payable to the finance undertaking by the borrower in respect of the asset over the consideration paid or payable by the finance undertaking for the asset is equivalent to the return on a loan of money at interest.

125. Paragraph (c), definition of "credit transaction", section 267(1) TCA 1997 as inserted by section 39 Finance Act 2010 (Irl),

(c) an arrangement whereby:

i. a finance undertaking and a borrower jointly acquire an asset, or

ii. a finance undertaking acquires an interest in an asset from a borrower, in circumstances where the borrower retains an interest in that asset.

126. While the Revenue Commissioners' Guidance Notes suggest that ijarāh wa-iqtina structures would fall within the provisions of the Finance Act 2010 (Irish Revenue Commissioners, "Guidance Notes on the Tax Treatment of Islamic Financial Transactions", op. cit., p. 13) such a claim is unfounded as the definitions of "credit transactions" provided for in the Act are not consistent with the structure of ijarāh wa-iqtina arrangements.

127. Section $267 \mathrm{O}(1)$ TCA 1997 as inserted by section 39 Finance Act 2010 (Irl).

128. Fahim Uz-Zaman, Shariah-Compliant Financial Services: A Guide to Products, Markets and Trends, London: VRL KnowledgeBank Ltd, 2006, p. 37; Reinhard Leopold Klarmann, Islamic Project Finance; a Legal Study with Particular Reference to the Laws of Switzerland and the United Arab Emirates, Zurich: Schulthess, 2003, p. 252.

129. Fahim Uz-Zaman, Shariah-Compliant Financial Services, op. cit., p. 37.

130. Irish Revenue Commissioners, "Guidance Notes on the Tax Treatment of Islamic Financial Transactions", op. cit., p. 29.

131. Section 73 Finance Act 2003 (UK) (c. 14).

132. Section 71A Finance Act 2003 inserted by s 94, Sch 8, paras 1, 2, Finance Act 2005 (UK).

133. Michael Ainley, et al., Islamic Finance in the UK, op. cit., p. 8.

134. Haider Ala Hamoudi, "The Death of Islamic Law", Georgia fournal of International and Comparative Law, Vol. 38, 2009-2010, pp. 293-338, see p. 302. 